\title{
NOTE
}

\section{Growth and sediment space occupation by seagrass Cymodocea nodosa roots}

\author{
Núria Marbà*, Carlos M. Duarte
}

Grup d'Oceanografia Interdisciplinar, Institut Mediterrani d'Estudis Avançats (CSIC-UiB), Miquel Marquès 21, 07190 Esporles (Illes Balears), Spain

\begin{abstract}
The development, growth, and space occupation by the canopy and rhizosphere of a temperate Mediterranean seagrass meadow of Cymodocea nodosa, and the possible effects of meadow seasonal development on sediment redox conditions, were examined during the 1998 growth season. The meadow supported maximum biomass of leaves and rhizomes during July, and maximum root biomass in August. The meadow maintained $123.6 \mathrm{~g}$ dry wt $\mathrm{m}^{-2}$ of leaves and $94.4 \mathrm{~g}$ dry wt $\mathrm{m}^{-2}$ of rhizomes (July data), and $121.2 \mathrm{~g}$ dry wt $\mathrm{m}^{-2}$ of roots (August data) during peak biomass. On average, the root network contained $607 \mathrm{~m}$ of roots $\mathrm{m}^{-2}$, had $3.6 \mathrm{~cm}$ between neighbouring roots and comprised $1.7 \%$ of sediment volume. Half of the root biomass occupied the top $12.6 \mathrm{~cm}$ of sediment, although a few roots reached $>35 \mathrm{~cm}$ sediment depth. The meadow developed 70,62 and $50 \%$ of leaf, rhizome and root biomass during the growth season respectively, showing that the structure of the temperate seagrass rhizosphere is highly dynamic. C. nodosa produced leaves, rhizomes and roots at rates ranging between 1.17 and $3.98 \mathrm{~g}$ dry wt $\mathrm{m}^{-2} \mathrm{~d}^{-1}, 0.01$ and $0.75 \mathrm{~g}$ dry wt $\mathrm{m}^{-2} \mathrm{~d}^{-1}$, and 0.04 and $0.84 \mathrm{~g}$ dry wt $\mathrm{m}^{-2} \mathrm{~d}^{-1}$, respectively. C. nodosa meadow grew on sediments where redox conditions during the growth season varied from -74 to $396 \mathrm{mV}$, being between 21 and $112 \mathrm{mV}$ more positive than adjacent unvegetated sediments from July to September. The magnitude of redox potential anomaly in seagrass rhizosphere tended to be coupled to the above and belowground meadow biomass, suggesting that C. nodosa metabolism alters sediment redox conditions. Structural change of seagrass meadows during the growth season, therefore, is expected to influence benthic biogeochemical processes.
\end{abstract}

KEY WORDS: Cymodocea nodosa - Growth season - Canopy · Rhizosphere $\cdot$ Biomass $\cdot$ Production $\cdot$ Redox potential $\cdot$ Sediment

\section{INTRODUCTION}

Seagrasses are key components of littoral habitats, supporting, on average, a greater biomass per unit area than other marine primary producers do (e.g.

*E-mail: ieanmb@clust.uib.es
Duarte \& Chiscano 1999). Seagrasses extend their active metabolic surfaces (i.e. leaves, rhizomes and roots) in the water column and in the sediment, where root activity may modify environmental conditions. Seagrass canopies efficiently attenuate waves (e.g. Fonseca \& Cahalan 1992), reduce velocity of currents (e.g. Gambi et al. 1990), decrease resuspension of sediments (e.g. Terrados \& Duarte 2000), and increase sediment nutrient fluxes (Nepf \& Koch 1999). Seagrass rhizospheres store organic matter (Pedersen et al. 1997), promote sulphate reduction (e.g. Holmer \& Nielsen1997), release oxygen (e.g. Pedersen et al. 1998) and increase redox potential (Enríquez et al. 2001) in the sediments they occupy.

Because the structure of temperate seagrass meadows varies seasonally (e.g. Duarte 1989), the possible effect of seagrass populations on the water column and sediments is expected to be larger during spring-summer, when plant modules are larger and most active, than in autumn-winter. While there have been numerous examples of the seasonal development of seagrass canopies, the patterns of occupation of the sediment by seagrass rhizospheres have received very limited attention (Duarte \& Chiscano 1999).

We provide a detailed study of the biomass, growth and the occupation of the space by the canopy and rhizosphere of a temperate Mediterranean seagrass meadow Cymodocea nodosa during the period of plant growth (June to October). We also examine the link between the development of the rhizosphere and the bulk biogeochemical conditions in the sediments.

\section{METHODS}

We examined the development of a patchy Cymodocea nodosa Mediterranean meadow growing at Blanes Bay, Spain $\left(41^{\circ} 40^{\prime} \mathrm{N}, 2^{\circ} 47^{\prime} \mathrm{E}\right)$. This meadow 
extended from $9 \mathrm{~m}$ to $>20 \mathrm{~m}$ depth, on fine sandy sediments containing $<1.4 \%$ organic matter (R. Sardà unpubl. data). The study was conducted between midJune and early October 1998, comprising the growth season of C. nodosa in this area (e.g. Cebrián et al. 1997).

At monthly intervals, 4 PVC sediment cores $(7 \mathrm{~cm}$ diameter, $50 \mathrm{~cm}$ length) were collected, 2 within the seagrass meadow and 2 on adjacent bare sediments. These PVC cores were vertically perforated at $2 \mathrm{~cm}$ intervals with $1.2 \mathrm{~cm}$ diameter holes. The holes were covered with tape to avoid the loss of pore water and sediment during sampling and transportation. In addition, duplicated samples of Cymodocea nodosa leaf canopy and rhizosphere were collected using a stainless steel core $(20 \mathrm{~cm}$ diameter, $50 \mathrm{~cm}$ length). These sediment samples were transferred underwater to 2 PVC pots of similar dimensions as the core to preserve the structure of the C. nodosa rhizosphere during transportation to the laboratory. To measure leaf and rhizome growth, 10 additional shoots and 10 rhizome apices were marked (Short \& Duarte 2001). The plant material marked during the previous sampling event was harvested, with priority given to collecting the longest possible rhizome pieces with intact roots. The sediment cores and plant material were rapidly transported to the laboratory, and the two $20 \mathrm{~cm}$ diameter cores were frozen prior to processing. The samples collected were used to estimate sediment redox potential, shoot density, aboveground biomass, leaf area index, rhizosphere structure (i.e. distance between roots, biomass depth distribution, root length $\mathrm{m}^{-2}$, root diameter and average number of branches $\operatorname{root}^{-1}$ ), as well as leaf, rhizome and root growth and production.

Sediment redox potential profiles were measured at $2 \mathrm{~cm}$ depth intervals on the $7 \mathrm{~cm}$ diameter PVC cores collected by inserting a Crison Pt electrode, connected to a portable $\mathrm{pH}$ meter (Crison model 507, Alella, Spain), horizontally into the sediments. The electrode was regularly calibrated with a redox standard solution (Crison $468 \mathrm{mV}$ ) at $25^{\circ} \mathrm{C}$, and cleaned and polished to prevent accumulation of Pt-oxides. Redox measurements were referred to the standard hydrogen electrode (207 mV) as described by APHA (1992). After measuring the redox potential, the Cymodocea nodosa cores were frozen at $-20^{\circ} \mathrm{C}$ and later sliced to estimate the distance between roots. The roots exposed on sediment surfaces were painted white to increase their contrast against the dark sediment, and these surfaces were recorded with a video camera. The distance between neighbouring roots was estimated as the average distance between each root and its closest neighbouring root on the filmed sediment cores using the image analysis program NIH Image/ppc $1.56 \mathrm{~b} 90$ (National Institute of Health, Bethesda, MD). Root vol- ume was estimated by dividing root fresh weight (fresh wt) by the density of the root material, which was assumed to equal $1 \mathrm{~g}$ fresh wt $\mathrm{cm}^{-3}$.

Shoot density was estimated as the number of shoots collected in all vegetated cores harvested (i.e. $\mathrm{N}=4,2 \times$ $7 \mathrm{~cm}$ diameter and $2 \times 20 \mathrm{~cm}$ diameter cores). Aboveground biomass was assessed from the leaf biomass collected in vegetated cores. Apex rhizome density was estimated from the apices collected within the $20 \mathrm{~cm}$ diameter cores. Belowground biomass was estimated from the total rhizome and root biomass harvested within all vegetated cores. Leaf area index was calculated as the product of the average one-sided leaf surface per shoot and the average shoot density. Biomass depth distribution in the Cymodocea nodosa rhizosphere was measured by slicing the $7 \mathrm{~cm}$ diameter cores at $2 \mathrm{~cm}$ depth intervals, and sorting and weighing roots and rhizomes after overnight desiccation at $60^{\circ} \mathrm{C}$.

We calculated the leaf growth rate, the rhizome elongation and rhizome internode formation rates from the marked plants following Short \& Duarte (2001). The position of each root on the retrieved rhizome pieces was recorded, and root length, diameter, number of branches and fresh wt measured. Knowledge of the number of rhizome internodes produced between sampling events allowed the reconstruction of the growth of the individual roots present along the rhizome. All measured leaves, rhizomes and roots were dried at $60^{\circ} \mathrm{C}$ for $24 \mathrm{~h}$ to estimate their dry wt and later their specific weight ( $g$ dry wt $\mathrm{cm}^{-2}$ ). Leaf production and rhizome production ( $g$ dry wt $\mathrm{m}^{-2} \mathrm{~d}^{-1}$ ) were estimated as the product of shoot elongation rate, leaf specific weight and shoot density, and as the product of the rhizome elongation rate, rhizome specific weight and density of rhizome apices, respectively. Root growth per rhizome apex was assessed as the sum of the weight of new roots produced in-between sampling events and the weight increment of the roots already present in previous sampling events. Root production was calculated as the product of the density of horizontal rhizome apices and the root growth per rhizome apex.

The redox potential anomaly associated to the presence of the rhizosphere was calculated as the difference between the average redox potential in vegetated and bare sediments at each depth interval. We use analysis of variance to test for temporal differences in redox anomaly. Standard errors of derived variables (average leaf, rhizome and root production) were calculated using the bootstrap procedure.

\section{RESULTS}

The Cymodocea nodosa meadow experienced substantial changes in above and belowground structure 
Table 1. Structural and dynamic properties of the Cymodocea nodosa meadow at Blanes bay (NE Spain) during the 1998 growth season. Data include average $\pm \mathrm{SE}$ (sample size). The probability (p) values refer to the significance of temporal variation $($ ANOVA, $\mathrm{ns}=\mathrm{p}>0.05)$. nd = data unavailable

\begin{tabular}{|c|c|c|c|c|c|c|}
\hline & Jun & Jul & Aug & Sep & Oct & $\mathrm{p}$ \\
\hline $\begin{array}{l}\text { Shoot density } \\
\left(\text { shoots } \mathrm{m}^{-2} \text { ) }\right.\end{array}$ & $964 \pm 115(8)$ & $1219 \pm 345(4)$ & $736 \pm 181(4)$ & $931 \pm 221$ & $837 \pm 213(4)$ & ns \\
\hline $\begin{array}{l}\text { Leaf biomass } \\
\text { (g dry wt } \mathrm{m}^{-2} \text { ) }\end{array}$ & $85.7 \pm 11.4(8)$ & $123.6 \pm 17.7(4)$ & $108.5 \pm 11.9$ & $73 \pm 9.8$ & $38.4 \pm 10.4$ & ns \\
\hline $\begin{array}{l}\text { Rhizome biomass } \\
\text { (g dry wt } \mathrm{m}^{-2} \text { ) }\end{array}$ & $81.7 \pm 11.2(8)$ & $94.4 \pm 14.5(4)$ & $60.2 \pm 9.3(4)$ & $58.7 \pm 9.8$ & $58.8 \pm 15.4(4)$ & ns \\
\hline $\begin{array}{l}\text { Root biomass } \\
\left(\mathrm{g} \text { dry wt } \mathrm{m}^{-2} \text { ) }\right.\end{array}$ & $62.5 \pm 5.6(8)$ & $97.9 \pm 10(4)$ & $121.2 \pm 11.7(4)$ & $110 \pm 9.2(4)$ & $64.1 \pm 5.6(4)$ & 0.002 \\
\hline $\begin{array}{l}\text { Leaf area index } \\
\left(\mathrm{m}^{2} \mathrm{~m}^{-2}\right)\end{array}$ & nd & 2.80 & 2.43 & 1.41 & 0.37 & \\
\hline $\begin{array}{l}\text { Root length } \\
\left(\mathrm{m} \mathrm{m}^{-2}\right)\end{array}$ & $544.4 \pm 51(8)$ & $589.6 \pm 86.4(4)$ & $822 \pm 155.5(4)$ & $686.6 \pm 49.7(4)$ & $394.4 \pm 39.9(4)$ & 0.04 \\
\hline $\begin{array}{l}\text { \% of sediment volume } \\
\text { occupied by roots }\end{array}$ & $1.5 \pm 0.3(8)$ & $2.2 \pm 0.4(4)$ & $2.8 \pm 0.8(4)$ & $1.3 \pm 0.3(4)$ & $0.8 \pm 0.2(4)$ & 0.05 \\
\hline Mean root diameter $(\mathrm{mm})$ & ) $\quad 1.07$ & 0.98 & 0.63 & 0.57 & 0.61 & \\
\hline $\begin{array}{l}\text { Branches 2nd order/ } \\
\text { main root }\end{array}$ & $0.15 \pm 0.31(136)$ & $0.82 \pm 0.36(102)$ & $2.81 \pm 0.34(110)$ & $3.72 \pm 0.30(145)$ & $3.03 \pm 0.37(97)$ & 0.00001 \\
\hline $\begin{array}{l}\text { Distance between } \\
\text { neighbouring roots (cm) }\end{array}$ & $7.08 \pm 0.74(50)$ & $4.55 \pm 0.22(249)$ & $2.56 \pm 0.14(236)$ & $1.63 \pm 0.12(150)$ & $2.41 \pm 0.3(44)$ & 0.00001 \\
\hline $\begin{array}{l}\text { Leaf production } \\
\text { (g dry wt } \mathrm{m}^{-2} \mathrm{~d}^{-1} \text { ) }\end{array}$ & nd & $3.98 \pm 1.01$ & $2.55 \pm 0.80$ & $1.17 \pm 0.34$ & $1.23 \pm 0.40$ & 0.00001 \\
\hline $\begin{array}{l}\text { Rhizome elongation } \\
\left(\mathrm{cm} \operatorname{apex}^{-1} d^{-1}\right)\end{array}$ & nd & $1.10 \pm 0.1(6)$ & $1.29 \pm 0.1$ & $0.49 \pm 0.1$ & $0.01 \pm 0.1(6)$ & 0.00001 \\
\hline $\begin{array}{l}\text { Rhizome production } \\
\left(\mathrm{g} \text { dry wt } \mathrm{m}^{-2} \mathrm{~d}^{-1}\right)\end{array}$ & nd & $0.75 \pm 0.43$ & $0.29 \pm 0.18$ & $0.22 \pm 0.16$ & $0.01 \pm 0.01$ & 0.00001 \\
\hline $\begin{array}{l}\text { Root production } \\
\left(\text { g dry wt } \mathrm{m}^{-2} \mathrm{~d}^{-1}\right)\end{array}$ & nd & $0.15 \pm 0.11$ & $0.84 \pm 0.06$ & $0.19 \pm 0.26$ & $0.04 \pm 0.03$ & 0.00001 \\
\hline $\begin{array}{l}\text { Root elongation } \\
\left(\mathrm{m} \mathrm{m}^{-2} \mathrm{~d}^{-1}\right)\end{array}$ & nd & $0.76 \pm 0.55$ & $5.09 \pm 0.36$ & $1.24 \pm 1.69$ & $0.40 \pm 0.3$ & 0.00001 \\
\hline
\end{tabular}

during the growth season. Changes in shoot density varied up to 1.6-fold, with maximal shoot density in July (Table 1), and a variability in shoot size. This resulted in wide fluctuations in aboveground biomass and leaf area index. The leaf canopy was fully developed in July (Table 1) and declined rapidly, being 3 -fold lower 3 mo later (Table 1).

Most of the Cymodocea nodosa rhizosphere was comprised within the upper $20 \mathrm{~cm}$ of sediment, as rhizomes did not reach below $20 \mathrm{~cm}$, and $50 \%$ of root biomass was always within the top $16 \mathrm{~cm}$ sediment depth (Fig. 1). Some roots ( $>5 \%$ of root biomass), however, penetrated below $35 \mathrm{~cm}$ (Fig. 1). The vertical structure of the rhizosphere changed greatly during the growth season. The root biomass was most uniformly distributed within the sediment, colonised deeper sediment layers in July, and was shallowest in August (Fig. 1). Rhizome biomass changed in parallel to the aboveground biomass,

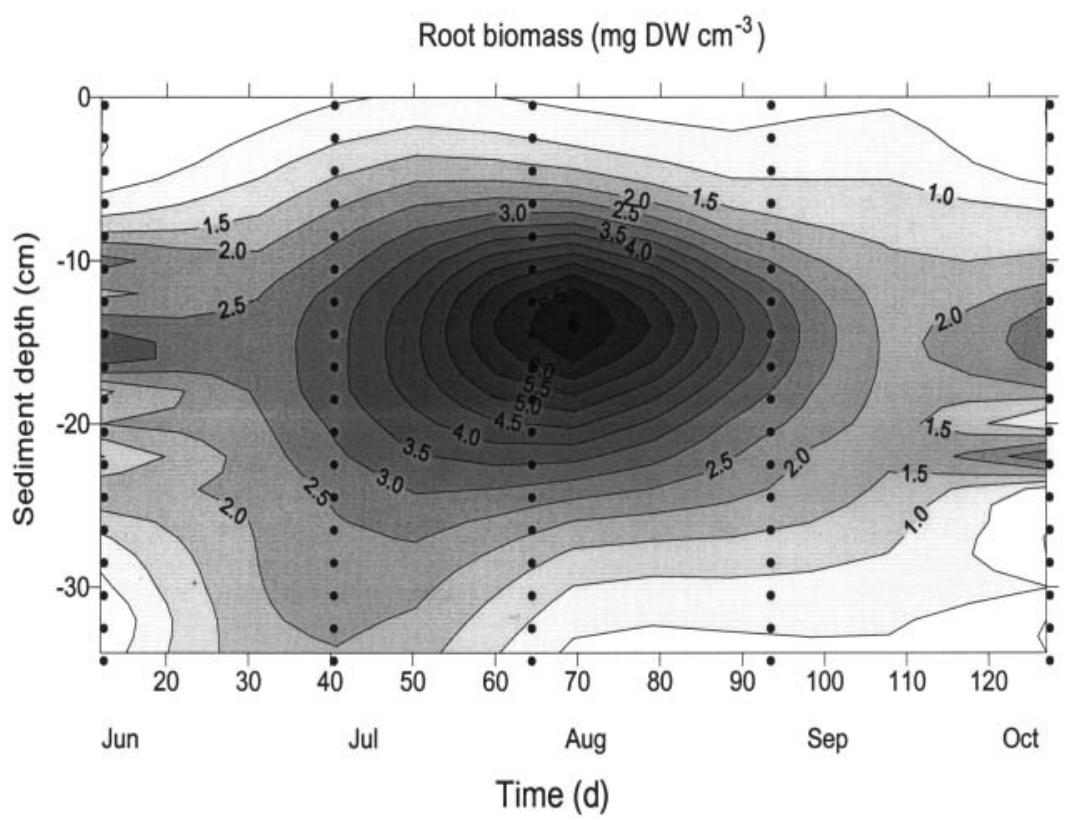

Fig. 1. Contour plot showing the evolution of root biomass within the Cymodocea nodosa rhizosphere. The time series started on June 1 1998. Dots indicate the sediment depths and times where root biomass was measured in duplicate samples 


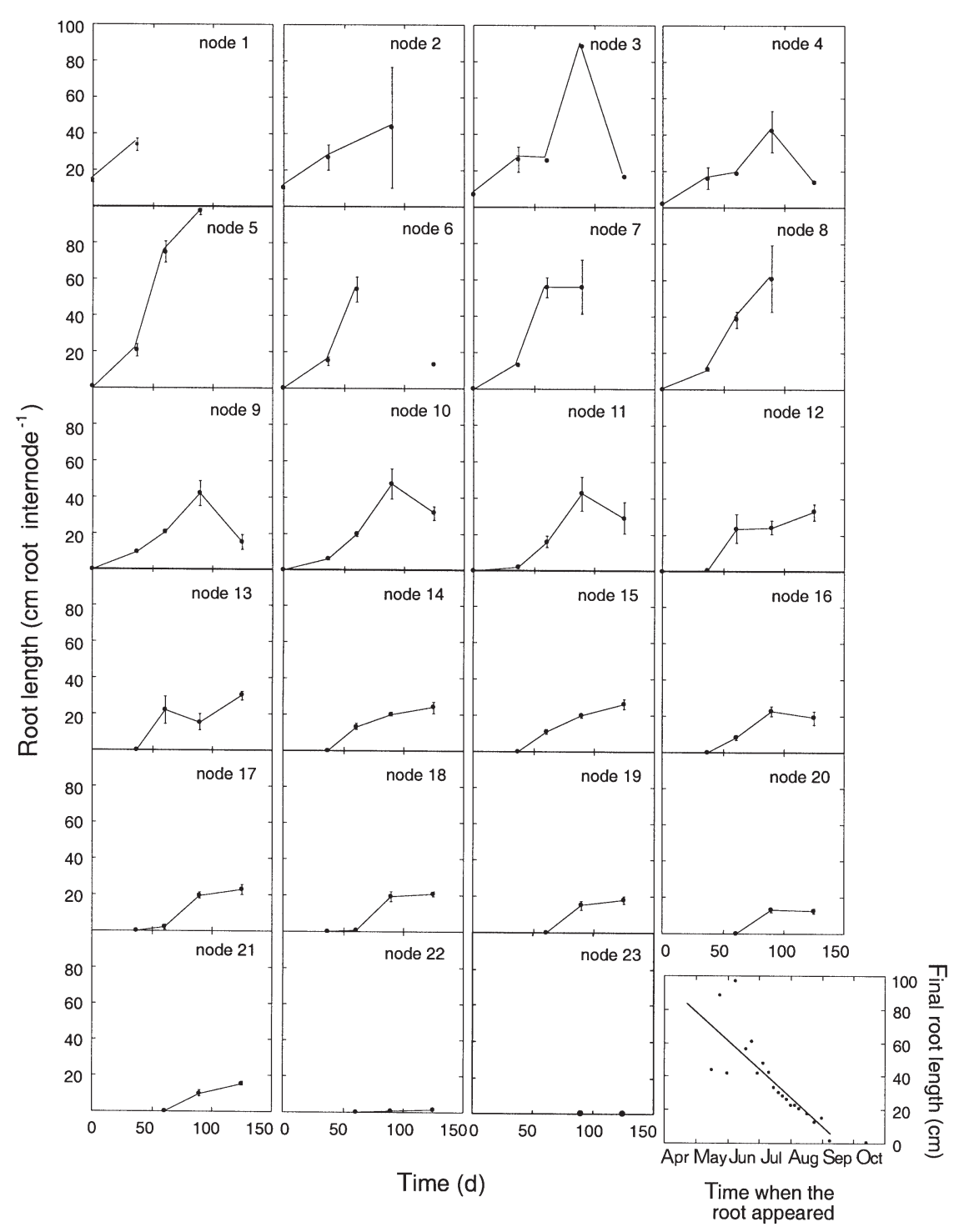

Fig. 2. Temporal changes in the length of roots produced during the growth season. The time series started on June 3, 1998. Bottom right panel shows the relationship between the maximum root length and the time when roots started to appear; the solid line represents the fitted regression equation: final root length $(\mathrm{cm})=146.6$ to $0.56 \times$ time $(\mathrm{d}) ; \mathrm{SE}_{\text {slope }}=0.084, \mathrm{R}^{2}=0.68, \mathrm{n}=21, \mathrm{p}<0.00001$. Error bars represent $\pm \mathrm{SE}$

reaching a maximum in July; whereas the C. nodosa root biomass reached a maximum in August, when it represented $45.5 \%$ of the total seagrass biomass (Table 1). The root network contained, on average, $607 \mathrm{~m}$ of roots $\mathrm{m}^{-2}$, a root surface of $1.47 \mathrm{~m}^{2} \mathrm{~m}^{-2}$, and comprised $1.7 \%$ of the sediment volume (Table 1$)$. The root length within the rhizosphere and the fraction of the sediment volume occupied by roots declined by 2fold between August and October (Table 1). The total root length showed a parallel change to that of the root biomass $(r=0.90, p<0.05)$, but the fraction of the sed- iment roots occupied showed a different pattern due to changes in root diameter. Roots were thinnest between August and October; the time when roots were most branched (Table 1). On average, neighbouring C. nodosa roots were spaced by $3.6 \mathrm{~cm}$ from one another, and this varied from $7 \mathrm{~cm}$ in June to $1.6 \mathrm{~cm}$ in September (Table 1).

Variability in meadow structure during the growth season largely resulted from fluctuations in leaf, horizontal rhizome and root production. Cymodocea nodosa leaves grew fastest in July (Table 1), the time when the meadow maintained the highest shoot density. Horizontal rhizome apices elongated at rates ranging from 0.03 to $1.29 \mathrm{~cm}_{\text {apex }}^{-1} \mathrm{~d}^{-1}$ (Table 1). Temporal changes in horizontal rhizome growth and differences in apex density resulted in 1 order of magnitude variation in rhizome production between July and October (Table 1). Maximum rates of horizontal rhizome production were reached in July (Table 1). On average, each ramet (i.e. physiological individual, composed by 1 shoot, roots, and in C. nodosa, 1 horizontal rhizome internode) presented 1.2 roots, and at least one of them was inserted on each node of horizontal rhizome. Some ramets older than 1 yr presented adventitious roots inserted on their vertical rhizomes. Roots were produced by C. nodosa horizontal rhizomes at an average rate of 0.15 roots apex ${ }^{-1} \mathrm{~d}^{-1}$, and a single horizontal rhizome produced 23 roots between May (the time rhizome starts to elongate, Marbà et al. 1996) and October. Moreover, roots appeared at rates 10 -fold faster in August than in October (Table 1). Roots grew fastest between July and August, and almost ceased growing in October (Table 1). Root growth rate closely depended on the time when the root appeared (Fig. 2). Roots produced early in the growth season (i.e. placed within rhizome nodes 3 to 8, May and June) grew faster than those produced later on in the growth season (Fig. 2). Maximum root length (including the main root and all branches) ranged from 0.4 to $97 \mathrm{~cm}$ (Fig. 2), depending on the time when the root was produced. Maximum C. nodosa root length decreased $0.5 \mathrm{~cm}$ after each day the growth season elapsed 
(regression analysis, $\mathrm{n}=21, \mathrm{R}^{2}=0.68$, $\mathrm{p}<0.0001$; Fig. 2). Variability in root growth rate and number of rhizome apices in the meadow lead to 1 order of magnitude changes in root production during the study period (Table 1), root production being highest in August (Table 1). C. nodosa produced between 0.4 and $5.1 \mathrm{~m}$ of roots $\mathrm{m}^{-2} \mathrm{~d}^{-1}$ (Table 1 ).

The redox potential in the sediments occupied by Cymodocea nodosa ranged between -74 and $396 \mathrm{mV}$, with positive redox potential down to at least $10 \mathrm{~cm}$ depth (Fig. 3). The redox potential at depths greater than $10 \mathrm{~cm}$ was often higher in vegetated than bare sediments, which maintained anoxic conditions throughout the study (Fig. 3). The positive redox potential anomaly associated to vegetated sediments was located between 4 and $23 \mathrm{~cm}$ in the sediment (Fig. 4), and averaged $63 \mathrm{mV}$. However, the magnitude of the positive redox anomaly exhibited large temporal and spatial fluctuations, being lowest in June and October, and greatest in July (Fig. 4). A negative redox anomaly was detected in the sediment surface between September and October (Fig. 4), suggesting enhanced microbial activity in .vegetated sediments, probably stimulated by the detritus produced by the declining seagrass meadow.
$E_{n}(m V)$
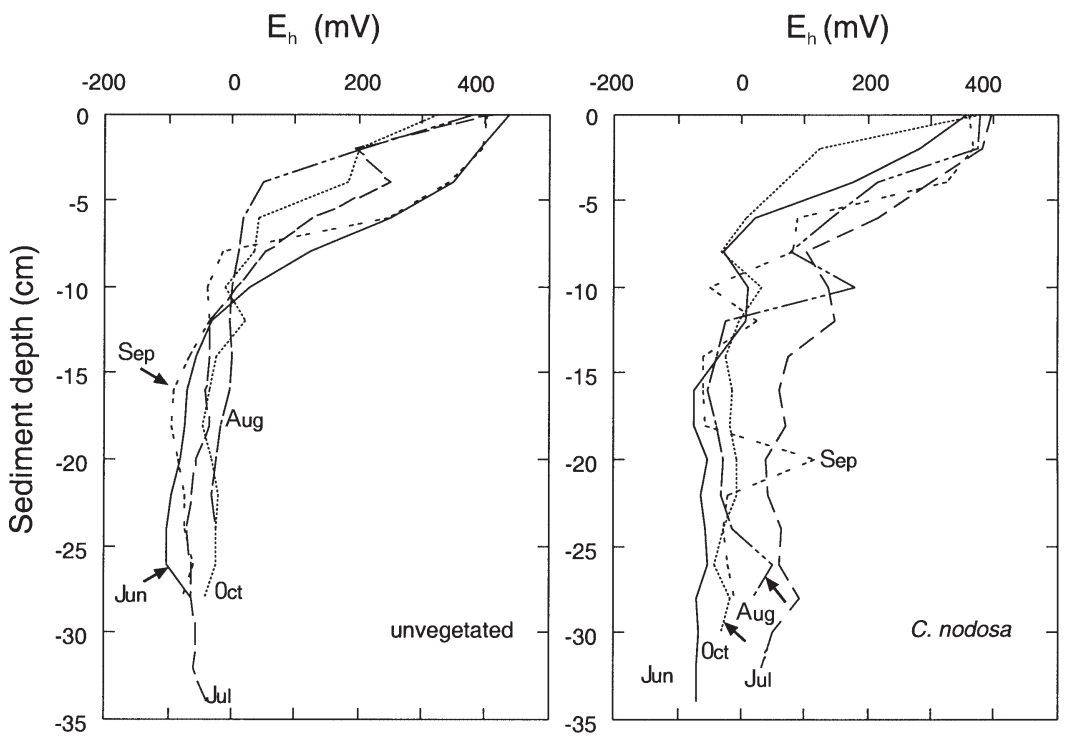

Fig. 3. Depth profiles of redox potential $\left(\mathrm{E}_{\mathrm{h}}\right)$ in unvegetated sediments and sediments colonised by Cymodocea nodosa during the 1998 growth season. Profiles represent the average of duplicate profiles per sampling event

rhizomes and roots, respectively. These results are similar to the annual production recorded in other C. nodosa beds (e.g. Peduzzi \& Vukovic 1990, Cebrián et al. 1997). This production resulted in a turnover rate of $2.23,0.44$ and 0.29 for leaf, rhizome and root biomass during the entire growth season. The root production in the $C$. nodosa meadow investigated was

\section{DISCUSSION}

The results presented demonstrate that the structure of the canopy and rhizosphere of Cymodocea nodosa meadows experience broad changes during the growth season, and that these changes are coupled to variability in redox conditions in the sediments colonised. The $C$. nodosa meadow studied produced most $(70 \%)$ of the aboveground, and $36 \%$ of the subterranean biomass within 5 mo. The root biomass of C. nodosa, however, increased $50 \%$ during the study period, and grew at rates as high as $5 \mathrm{~m} \mathrm{~m}^{-2} \mathrm{~d}^{-1}$. Hence, the subterranean structure of $C$. nodosa meadows experiences changes during the growth season of similar magnitude as those observed in the leaf canopy. The C. nodosa meadow studied produced $275.7 \mathrm{~g}$ dry wt $\mathrm{m}^{-2}, 41.4 \mathrm{~g}$ dry wt $\mathrm{m}^{-2}$, and $34.5 \mathrm{~g}$ dry wt $\mathrm{m}^{-2}$, of leaves,

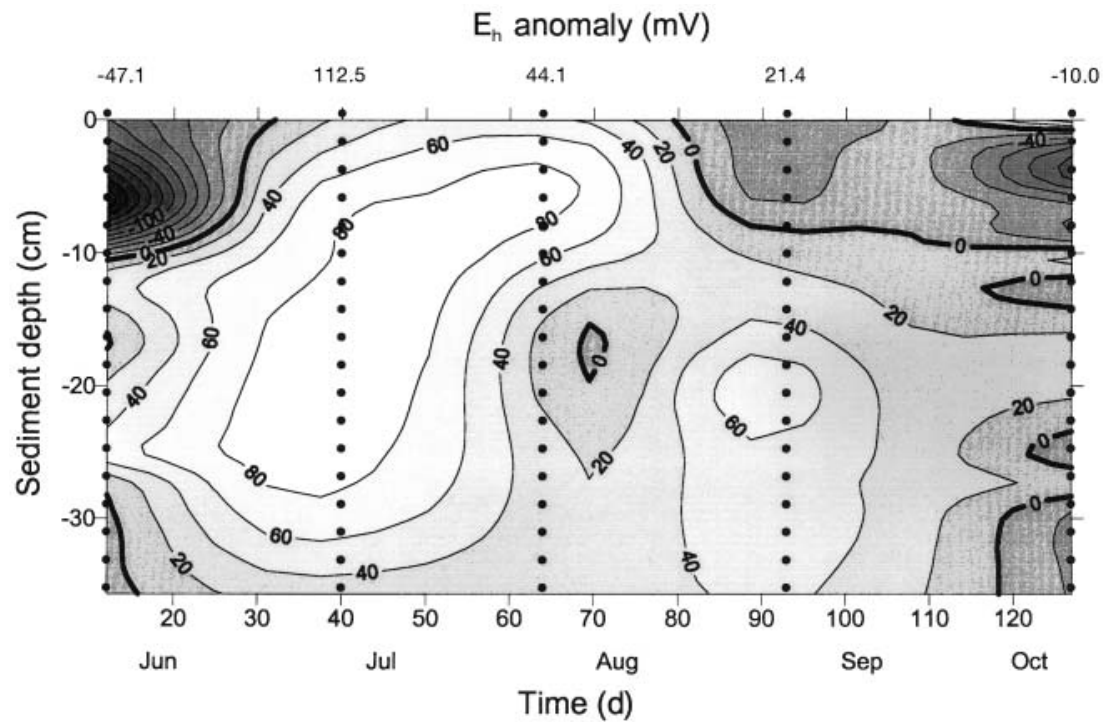

Fig. 4. Contour plot showing the evolution of the redox potential $\left(E_{h}\right)$ anomaly associated to Cymodocea nodosa rhizosphere (i.e. redox anomaly $=$ redox vegetated - redox unvegetated). The time series started on June 1, 1998. Dots indicate the sediment depths and times where redox potential anomaly was measured in duplicate. The average redox potential anomaly for each sampling event is shown on the top of the panel 
lower than the annual root production reported for other C. nodosa meadows (Cebrián et al. 1997, Duarte et al. 1998), probably because this meadow was less dense and grew much deeper than previous studied meadows (11 $\mathrm{m}$ vs 1 to $3 \mathrm{~m}$ ).

The results presented clearly show that the seagrass rhizosphere is a highly dynamic compartment, despite the general neglect of root production in the literature. Until 1996, the literature on seagrass had only reported 17 estimates of root production, compared with the 128 reported for aboveground production (Duarte \& Chiscano 1999). In addition, there is only one other report of seasonal changes in seagrass root production (Cebrián et al. 1997). Despite the scarcity of estimates of seagrass rhizosphere dynamics, the few data available on the development of the rhizosphere structure of temperate seagrass meadows indicate that belowground production must be large. For instance, the rhizosphere biomass has been reported to vary between 2- and 5-fold over the growth season in temperate seagrasses (e.g. Sand-Jensen 1975, Cebrián et al. 1997). Insufficient awareness of the high dynamics of seagrass rhizosphere growth has probably lead to a $25 \%$ underestimate of seagrass annual production (Duarte \& Chiscano 1998).

The maximum root biomass was reached 1 mo after the canopy reached its maximum biomass (Table 1). This suggests a shift of resource limitation from light to nutrient-limitation towards the end of the growth season, which is consistent with reports that self-shading by the Cymodocea nodosa canopy occurs during peak leaf biomass (Pérez \& Romero 1992), and nutrient-limited C. nodosa growth in mid- to late summer (Pérez et al. 1991), when root production is highest (Table 1). The high root production during August was $>4$-fold higher than that observed during the growth period (Table 1). This may account for a large fraction of the nutrient demand by the plant.

The studied Cymodocea nodosa meadow had, on average, more $(20 \%)$ adsorptive surface within the water column than in the sediments. However, the surface of C. nodosa rhizosphere was 2 times higher than the canopy in October (Table 1). The average root surface of the studied $C$. nodosa meadow was relatively high when compared with that of other seagrass rhizospheres (Duarte et al. 1998), suggesting that the C. nodosa rhizosphere should play an important role in the biogeochemical processes in vegetated sediments. Indeed, an increase in the biomass of the $C$. nodosa rhizosphere was linked to an increase in the size of the positive anomalies in sediment redox conditions (Table 1).

The highest positive redox anomaly observed within the Cymodocea nodosa rhizosphere was, however, lower than that in sediments vegetated with Zostera noltii (average positive redox anomaly for the entire sediment profile $=189 \mathrm{mV}$; Isaksen \& Finster 1996), in sediments colonised by vascular freshwater macrophytes in nature (range $E_{h}$ anomlay in sediments colonised by isoetides, 300 to $440 \mathrm{mV}$; Wium-Andersen \& Andersen 1972, Jaynes \& Carpenter 1986) or laboratory experiments (Myriophyllum verticillatum L., redox anomaly up to $90 \mathrm{mV}$; Typha latifolia, redox anomaly ca $118 \mathrm{mV}$; Carpenter et al. 1983, Jespersen et al. 1998). Conversely, redox potential in the bare sediments observed during this study (Fig. 3) fall within the upper range of redox conditions reported for nonvegetated sediments (e.g. Wium-Andersen \& Andersen 1972, Jaynes \& Carpenter 1986, Isaksen \& Finster 1996, Enríquez et al. 2001). This comparison suggests that the extent of the effect of rooted aquatic vegetation on sediment redox conditions depends on plant species and/or their metabolic activity, as the C. nodosa stand studied here is the deepest one where plant effects on redox conditions have been tested.

The density of the Cymodocea nodosa rhizosphere was highest in August, at $1.84 \mathrm{mg}$ dry wt root $\mathrm{cm}^{-3}$. Oxygen release into seagrass rhizospheres has been shown to reach out to $80 \mu \mathrm{m}$ from the root surfaces (Pedersen et al. 1998); therefore, the distance between neighbouring roots becomes a critical determinant of the extent of the effects of seagrass rhizospheres on sediment conditions. The minimum distance between neighbouring roots observed was $1.6 \mathrm{~cm}$, which is far greater than the $80 \mu \mathrm{m}$ assumed to comprise rhizosphere effects (Pedersen et al. 1998). Yet our results on redox anomalies clearly demonstrate that the $C$. nodosa rhizosphere affected bulk sediment conditions even at distances of $7 \mathrm{~cm}$ in-between neighbouring roots. This observation suggests that the range of rhizosphere effects on sediment conditions must be far greater than indicated by microelectrode assessments. The release of oxygen into the sediments may increase the oxidation of reduced compounds (e.g. iron, sulphide) by creating a suboxic zone, where redox potentials would be higher than those in the reduced zone. The release of oxygen from the plants may thus indirectly increase the redox potential.

The Cymodocea nodosa meadow grew in an area where sediment redox conditions varied between -100 and $>0 \mathrm{mV}$ (Fig. 3), indicating that the Fe(II)/Fe(III) system was the most important redox couple for organic matter oxidation (Stumm \& Morgan 1981). However, seagrass meadows may grow on sediments with redox potential <-200 $\mathrm{mV}$ (Terrados et al. 1999), where early diagenesis is mediated by sulphate reduction and methane fermentation (cf. Stumm \& Morgan 1981). There is evidence that seagrass growth and survival is reduced when sulphide concentration in the sediment increases (Terrados et al. 1999). Moreover, the fast decline of some seagrass meadows (e.g. Tha- 
lassia testudinum in Florida Bay) has been attributed to the increase of toxic compounds in the sediment (e.g. sulphide) produced by microbial degradation of organic matter (Carlson et al. 1994, but see Zieman et al. 1999). The magnitude of the positive redox potential anomaly induced by Cymodocea nodosa meadow ranged between 26 and $>100 \mathrm{mV}$ (Fig. 4), and is sufficient to shift from more reduced processes (sulphate reduction) to more oxidised processes (iron reduction). This increase in redox conditions within the seagrass rhizosphere may help to avoid accumulation of phytotoxins such as sulphide in the sediment, suggesting that seagrass meadows may improve the capacity of the sediments colonised to support plant life. The increase of redox potential derived from seagrass activity, conversely, may enhance phosphorous binding to iron, and, hence, reduce the availability of sediment phosphorous for plant growth.

There is ample evidence that seagrass growth and production are closely dependent on sediment conditions, as growth is often enhanced upon nutrient additions to the sediments (Duarte 1990). There is also evidence of negative effects of high organic matter content, low redox potential, and high sulphide concentrations in sediments (Terrados et al. 1999). However, the effects of seagrasses on sediment conditions have received far less attention, although enhanced sulphate reduction rates in vegetated sediments have been reported (e.g. Holmer \& Nielsen 1997). Our results clearly showed that the belowground structure of temperate seagrass meadows can be highly dynamic, which is expected to impose an important variability on benthic biogeochemical processes.

Acknowledgements. This work was funded by the project PhaSE (contract MAS3-CT96-0053) of the ELOISE programme of the European Union. N.M. was supported by a grant from the CIRIT (Government of Catalonia). We thank Rafa Sardá for providing unpublished data on sediment characteristics, Jack Middelburg for helpful advice, and 3 anonymous reviewers for useful comments on the manuscript.

\section{LITERATURE CITED}

APHA (American Public Health Association) (1992) Oxidation-reduction potential measurement in clean water. In: Standard methods for the examination of water and wastewater. 18th edn. APHA, Washington, DC, p 260-263

Carlson PR Jr, Yarbro LA, Barber TR (1994) Relationship of sediment sulfide to mortality of Thalassia testudinum in Florida Bay. Bull Mar Sci 54:733-746

Carpenter SR, Elser JJ, Olson KM (1983) Effects of roots of Myriophyllum verticillatum L. on sediment redox conditions. Aquat Bot 17:243-249

Cebrián J, Duarte CM, Marbà N, Enríquez S (1997) The magnitude and fate of the production of four co-ocurring
Western Mediterranean seagrass species. Mar Ecol Prog Ser 155:29-44

Duarte CM (1989) Temporal biomass variability and production/biomass relationships of seagrass communities. Mar Ecol Prog Ser 51:269-276

Duarte CM (1990) Seagrass nutrient content. Mar Ecol Prog Ser 67:201-207

Duarte CM, Chiscano CL (1999) Seagrass biomass and production. Aquat Bot 65:159-174

Duarte CM, Merino M, Agawin NSR, Uri J, Fortes MD, Gallegos ME, Marbà N, Hemminga MA (1998) Root production and belowground seagrass biomass. Mar Ecol Prog Ser 171:97-108

Enríquez S, Marbà N, Duarte CM, van Tussenbroek B, Reyes G (2001) Effects of seagrass Thalassia testudinum on sediment redox conditions. Mar Ecol Prog Ser 219:149-158

Fonseca MS, Cahalan JA (1992) A preliminary evaluation of wave attenuation by four species of seagrass. Estuar Coast Shelf Sci 35:565-576

Gambi MC, Nowell A, Jumars P (1990) Flume observations on flow dynamics in Zostera marina (eelgrass) beds. Mar Ecol Prog Ser 61:159-169

Holmer M, Nielsen SL (1997) Sediment sulfur dynamics related to biomass-density pattern in Zostera marina (eelgrass) beds. Mar Ecol Prog Ser 146:163-171

Isaksen MF, Finster K (1996) Sulphate reduction in the root zone of the seagrass Zostera noltii on the intertidal flats of a coastal lagoon (Arcachon, France). Mar Ecol Prog Ser 137:187-194

Jaynes ML, Carpenter SR (1986) Effects of vascular and nonvascular macrophytes on sediment redox and solute dynamics. Ecology 67:875-882

Jespersen DN, Sorrell BK, Brix H (1998) Growth and root oxygen release by Typha latifolia and its effects on sediment methanogenesis. Aquat Bot 61:165-180

Marbà N, Cebrián J, Enríquez S, Duarte CM (1996) Growth patterns of Western Mediterranean seagrasses: speciesspecific responses to seasonal forcing. Mar Ecol Prog Ser 133:203-215

Nepf HM, Koch EW (1999) Vertical secondary flows in submersed plant-like arrays. Limnol Oceanogr 44:1072-1080

Pedersen MF, Duarte CM, Cebrián J (1997) Rates of changes in organic matter and nutrient stocks during seagrass Cymodocea nodosa colonization and stand development. Mar Ecol Prog Ser 159:29-36

Pedersen O, Borum J, Duarte CM, Fortes MD (1998) Oxygen dynamics in the rhizosphere of Cymodocea rotundata. Mar Ecol Prog Ser 169:283-288

Peduzzi P, Vukovic A (1990) Primary production of Cymodocea nodosa in the Gulf of Trieste (Northern Adriatic Sea): a comparison of methods. Mar Ecol Prog Ser 64:197-207

Pérez M, Romero J (1992) Photosynthetic response to light and temperature of the seagrass Cymodocea nodosa and the prediction of its seasonality. Aquat Bot 43:51-62

Pérez M, Romer OJ, Duarte CM, Sand-Jensen K (1991) Phosphorus limitation of Cymodocea nodosa growth. Mar Biol 109:129-133

Sand-Jensen K (1975) Biomass, net production and growth dynamics in an eelgrass (Zostera marina) population in Vellerup Vig, Denmark. Ophelia 14:185-201

Short FT, Duarte CM (2001) Methods for the measurement of seagrass growth and production. In: Short FT, Coles RG (eds) Global seagrass research methods. Elsevier Science Publishers, Amsterdam, p 155-182

Stumm WS, Morgan JJ (1981) Aquatic chemistry. Wiley-Liss Inc., New York

Terrados J, Duarte CM (2000) Experimental evidence of 
reduced particle resuspension within a seagrass (Posidonia oceanica L.) meadow. J Exp Mar Biol Ecol 243:45-53 Terrados J, Duarte CM, Kamp-Nielsen L, Borum J and 6 others (1999) Are seagrass growth and survival affected by reducing conditions in the sediment? Aquat Bot 65: 175-197

Wium-Andersen S, Andersen JM (1972) The influence of

Editorial responsibility: Otto Kinne (Editor),

Oldendorf/Luhe, Germany vegetation on the redox profile of the sediment of Grave Langsø, a Danish Lobelia lake. Limnol Oceanogr 17: 948-952

Zieman JC, Fourqurean JW, Frankovich TA (1999) Seagrass die-off in Florida Bay: long-term trends in abundance and growth of turtle grass, Thalassia testudinum. Estuaries 22: $460-470$

Submitted: January 21, 2001; Accepted: August 2, 2001

Proofs received from author(s): November 27, 2001 